\title{
PROBLEMATIKA KOMERSIALISASI EMPLOYEE INVENTION PADA INSTANSI PEMERINTAH \\ (Studi Kementerian Kelautan dan Perikanan dan Kementerian Pertanian)
}

\author{
Ayu Wulansari Raharningtyas M.1, Kholis Roisah² \\ Program Studi Magister Ilmu Hukum \\ Fakultas Hukum Universitas Diponegoro \\ r_kholis@yahoo.com
}

\begin{abstract}
ABSTRAK
Pelaksanaan komersialisasi hasil temuan Inventor ASN menjadi kewajiban Litbang karena biaya kegiatan penelitian dibiayai oleh negara. Komersialisasi pada prakteknya tidak berjalan lancar. Tujuan penelitian untuk menganalisis pelaksanaan dan hambatan proses komersialisasi pada Kementerian Kelautan dan Perikanan (KKP) dan Kementerian Pertanian. Metode penelitian yang digunakan adalah pedekatan yuridis empiris., dengan pelaksanaan penelitian di KKP dan Kementerian Pertanian. Ditemukan bahwa setiap kementerian memiliki metode komersialisasi terhadap invensi masing-masing inventor berbeda-beda. Perbedaan dalam metode komersialisasi berefek dalam keberhasilan Balitbang mengkomersialkan sebuah invensi. Simpulan penulisan adalah terdapat beberapa kendala dalam proses komersialisasi invensi, baik itu kendala dari pihak Balitbang maupun dari pihak Inventor ASN. Kendala komersialisasi menimbulkan dampak para Inventor ASN tidak bisa menerima kompensasi dari invensi tersebut bilamana tidak berhasilnya invensi tersebut tidak mampu dikomersialisasikan.
\end{abstract}

Kata kunci: Balitbang; Employee Invention; Komersialisasi

\footnotetext{
${ }^{1}$ Mahasiswa Program Studi Magister IImu Hukum UNDIP

2 Penulis Kedua, Penulis Koresponden
} 


\section{A. PENDAHULUAN}

Hak Kekayaan intelektual merupakan kekayaan atas segala hasil produksi kecerdasan daya pikir seperti teknologi, pengetahuan, sastra, seni, karya tulis, karikatur, pengarang lagu dan seterusnya yang memberikan pengaruh signifikan terhadap peradapan manusia. Bentuk penghargaan terhadap karya intelektual seseorang tersebut yang diwujudkan dalam bentuk pengakuan dan perlindungan yang di atur dalam Trade Related Aspec of Intellectua Property Rights (TRIPS) di bawah wewenang WTO. ${ }^{3}$

TRIPs mengklasifikasikan Hak kekayaan Intelektual terdiri atas delapan jenis salah satunya adalah Paten (Patent. Paten adalah salah satu objek penting dalam Hukum Kekayaan Intelektual. WIPO memberi definisi terhadap Paten4:"A Patent is a legally enforceable right granted by virtue of law to a person to exclude, for a limited time, other from certain acts in relation to describe new invention; the privilege is granted by a government authority as a matter of right to the person who is entitled to apply for it and who fulfils the prescribed condition".

Hak Paten memberi perlindungan terhadap Inventor. Inventor adalah orang yang membuat suatu penemuan, dimana penemuan tersebut disebut invensi. Pengertian Invensi menurut Pasal

\footnotetext{
${ }^{3}$ Kholis Roisah. Dinamika Perlindungan HKI Indonesia Dalam Tatanan G lobal(Semarang : Pustaka Magister, 2013) halaman 9-10

${ }^{4}$ Muhammad Djumhana dan R. Djubaedillah, 2014, Hak Milik Intelektual Sejarah, Teori dan Praktiknya di Indonesia, hal.161
}

ayat 1 ayat 2 Undang-undang No. 13 Tahun 2016 tentang Paten adalah ide inventor yang dituangkan ke dalam suatu kegiatan pemecahan masalah yang spesifik di bidang teknologi berupa produk atau proses, atau penyempurnaan dan pengembangan produk atau proses.

Penemuan atau invensi yang dihasilkan oleh penemu atau inventor baik yang bekerja pada perusahaan atau dari sebuah hubungan dinas disebut employee invention. $\mathrm{Di}$ Indonesia hubungan kerja yang karyawan atau tenaga kerja mereka aktif melakukan penelitian-penelitian dalam menemukan inovasi baru, yaitu Instansi pemerintah dan Perusahaan-perusahaan. Pengertian Employee Invention, yaitu merupakan penemuan, usulan perbaikan teknis yang di buat oleh karyawan dalam pekerjaan swasta, karyawan dalam pelayanan public oleh Pegawai Negeri ataupun oleh anggota angkata bersenjata. Pada Undangundang No. 13 Tahun 2016 tentang Paten pengaturan Inventor ASN diatur pada Pasal 13.

Lembaga penelitian dan pengembangan (litbang) memiliki peran penting dalam ekonomi nasional. Hal ini ditandai dengan teknologi yang dihasilkan bersumber dari sebuah kegiatan penelitian yang bersifat komersial. Sehingga suatu proses komersialisasi merupakan hal yang penting bagi produktivitas suatu invesi untuk menunjang perkembangan ekonomi nasional. Sehingga suatu employee invention yang dihasilkan oleh Litbang instansi pemerintah wajib untuk dikomersialisasikan melalui perjanjian lisensi dengan pihak ketiga. 
Kegiatan komersial adalah suatu kegiatan yang dilakukan oleh orang baik pribadi atau badan yang bertujuan untuk mendapatkan suatu keuntungan, baik secara langsung ataupun tidak langsung. ${ }^{5}$

Peran Lembaga penelitian dan pengembangan (litbang) dalam melahirkan sebuah temuan tidak hanya terpaku pada proses komerisalisasi. Peran litbang telah dimulai semenjak suatu inovasi tersebut baru berbentuk perencanaan. Poses selanjutnya adalah melakukan pendaftaran kepada DitJen Kekayaan Intelektual, setalah invensi tersebut terdaftar baru proses komersialisasi dimulai dengan diawali mencari Calon Pihak Ketiga, lalu Proses Mediasi, Proses Penyusunan Naskah Perjanjian, Proses Penandatangan Perjanjian Lisensi, ProsesVerifikasi.

Banyaknya proses yang dilalui oleh Lembaga penelitian dan pengembangan dalam proses komersialisasi tidaklah didukung dengan optimalnya komersialisasi hasil invensi. Praktek yang terjadi dilapangan, masih minimnya jumlah lisensi yang dihasilkan oleh litbang dari penelitian yang telah terdaftar. Menurut seminar National Exhibition of Invention di Cina $2015^{6}$, mengatakan penemuan atau penelitian memiliki masalha dalam memahami kebutuhan pasar, mengevaluasi ulang paten mereka dan bekerja sam dengan orang lain. Selain itu masalah terbasar bagi penemu adalah

5 Pasal 1 Ayat 9a Peraturan Daerah Kota Bukit Tinggi Nomo 2 Tahun 2016 tentang Retribusi Tempat Rekreasi dan Olahraga ${ }^{6} \mathrm{http}: / /$ www.chinadaily.com.cn/beijing/201508/19/content 21645081.htm; diakses tanggal 28 Februari 2017; pukul $1 \overline{4} .09$ wib kurangnya dana dan investasi dimana bagi para litbang mengajukan dana pemerintah dan sejumlah lembaga masilah belum mencungkupi kebutuhan dalam memnuhi pemintaan konsumen.

Berdasar uraian tersebut penulis tertarik melakukan penelitian terhadap kendala-kendala yang dihadapi oleh instansi pemerintah dalam mengkomersialkan hasil invensi : (1) bagaimana proses komersialisasi yangdilakukan pada instansi pemerintah ;2) Apa sajakah kendala-kendala yang ditemui pada proses komensialisasi hasil penelitian di Litbang Instansi pemerintah; (3) apasaja yang menjadi faktor terjadinya kendala pada proses komersialisasi.

Instansi pemerintah yang dijadikan penulis sebagai tempat penelitian adalah Kementerian Kelautan dan Perikanan dan Kementerian Pertanian. Kementerian Kelautan dan Perikanan adalah kementerian yang memiliki Sentra HKI yang berdiri pada tahun 2004 yang telah menghasilkan 72 pendaftaran paten dan berhasil menghasilkan 15 sertifikat paten. Kementerian Pertanian memiliki Sentra HKI yang berdiri pada tahun 1974 yang telah menghasilkan 162 pendaftaran paten dan berhasil menghasilkan 72 sertifikat paten.

Penulis menilai perusahan tersebut memenuhi perameter instansi pemerintah yang aktif melaksanakan penelitian dan menghasilkan hasil penelitian berupa inovasi dan melaksanakan prosedur komersialisasi sehingga menjadi intepretasi yang sesuai untuk menjawab rumusan 
permasalahan. Sehingga oleh penulis dipilihlah judul sebagai berikut :

\section{PROBLEMATIKA KOMERSIALISASI EMPLOYEE INVENTION PADA INSTANSI PEMERINTAH}

(Studi Kementerian Kelautan dan Perikanan dan

\section{Kementerian Pertanian)}

\section{Metode Penelitian}

Penelitian merupakan suatu kegiatan ilmiah yang berusaha untuk memecahkan masalahmasalah secara sistematis dengan menggunakan metode-metode tertentu dan teknik-teknik tertentu. ${ }^{7}$ Penelitian hukum ini, penulis menggunakan metode penelitian yang telah ditentukan yaitu : penelitian yuridis empiris. Pendekatan yuridis empiris dilakukan dengan cara melihat kenyataankenyataan hukum yang ada di lapangan yang berupa sikap, aktivitas Litbang dalam pelaksanaan komersialisasi pada 2 instansi pemerintah adalah Kementerian Kelautan dan Perikanan (KKP) dan Kementerian Pertanian, dan pendapat hukum para subjek penelitian tentang pokok permasalahan dalam penelitian ini.

Spesifikasi penelitian yang digunakan bersifat deskriptif analitis ${ }^{8}$, yaitu Deskriptif berarti menggambarkan objek penelitian yaitu proses komersialisasi hasil penelitian pada Kementerian Kelautan dan Perikanan (KKP) dan Kementerian Pertanian dan kendala-kendala yang terjadi pada

\footnotetext{
7 Soerjono Soekanto, Pengantar Penelitian Hukum ( Jakarta UI Press,1984) hal 45

8 Hadari Nawawi \& Mimi Martini, Penelitian Terapan;

Yogyakarta: 1994. Hal 73
}

proses komersialisasi. Sedangkan analitis yaitu mengetahui apa yang menjadi faktor terjadinya kendala dalam proses komersialisasi. ${ }^{9}$

Data yang digunakan adalah data primer dan data sekunder, data sekunder di dapat dari wawancara mendalam dan data sekunder di dapatkan dari bahan hukum primer dan sekunder. ${ }^{10}$

\section{Tujuan Penelitian}

Tujuan penelitian untuk menganalisis pelaksanaan dan hambatan proses komersialisasi pada Kementerian Kelautan dan Perikanan (KKP) dan Kementerian Pertanian.

\section{B. PEMBAHASAN}

1. Profil Invensi pada Kementerian Kelautan dan Perikanan (KKP) DAN Kementerian Pertanian

\section{a. Kementerian Kelautan dan Perikanan (KKP)}

Kementerian Kelautan dan Perikanan adalah kementerian yang memiliki Sentra HKI yang berdiri pada tahun 2004 dengan Dasar Hukum Pembentukan Sentra HKI Kementerian Kelautan dan Perikanan Keputusan Menteri Kelautan dan Perikanan RI Nomor KEP. 40/MEN/2004 tentang Tim Ad hoc Sentra Hak Kekayaan Intelektual Departemen Kelautan dan Perikanan dan telah menghasilkan 72

\footnotetext{
9 Bambang Sunggono, Metode Penelitian Hukum, (Jakarta : PT RajaGrafindo Persada, 2006), hal 97-98

10 Muhammad Idrus, Metode Penelitian IImu-IImu Sosial (yogyakarta : UII Press Yogyakarta (anggota IKAPI), 2007), hal 179
} 
pendaftaran paten dan berhasil menghasilkan 15 sertifikat paten.

\section{b. Kementerian Pertanian}

Kementerian Pertanian memiliki Sentra HKI yang berdiri pada tahun 1974 yang telah menghasilkan 162 pendaftaran paten dan berhasil menghasilkan 72 sertifikat paten.

\section{Proses komersilaisasi pada instansi pemerintah}

Peran balitbang pada Instansi pemerintah memegang peran sangat penting, melalui Litbang suatu invensi bisa mendapat perlindunga Hak Kekayaan Intelektual dan Litbang juga melakukan usaha untuk membuat invensi tersebut bisa di prosuksi sehingga bisa dinikmati oleh masyarakat.

\section{a. Proses Pendaftaran Hak Kekayaan Intelektual}

Proses pendaftaran dimulai dengan mekanisme pengalihan teknologi dari Inventor kepada Satuan Kerja lalu kepada Badan Litbang. Pendaftaran HKI dilakukan melalui satu pintu yaitu Badan litbang sebagai kuasa pendafataran HKI. Perlindungan HKI diperlukan guna memberikan kepastian hukum bagi pengusaha yang akan melisensikan dan menghindari penyalahguanaan oleh pihak-pihak yang tidak bertanggung jawab.

\section{b. Proses Promosi}

Hasil penelitian yang sudah didaftarkan HKI dan memenuhi kelayakan teknis untuk dikomersialkan kemudian dipromosikan kepada masyarakat, khususnya dunia usaha, melalui publikasi, forum temu bisnis, dan komunikasi bisnis (misalnya promosi door to door keperusahaan sesuai dengan klaster teknologinya). Dari hasil kegiatan promosi tersebut selanjutnya dilakukan penjaringan mitra yang berminat, baik secara langsung pada waktu promosi maupun secara tidak langsung setelah dilakukan promosi.

\section{c. Proses Seleksi Calon Mitra}

Mitra yang berminat melisensi dapat mengajukan permohonan dalam bentuk surat minat kepada Kepala Badan Litbang tentang teknologi yang diminati dengan melampirkan Company Profile, Akat pendirian Perusahaan, SIUP, NPWP dan data fasilitas pendukung pengembangan teknologi yang dilisensi. setelah memperoleh disposisi dari Kepala Badan litbang, maka dilakukan seleksi terhadap calon mitra kerjasama dengan cara presentasi oleh calon mitra mengenai bidang usahanya, alasan untuk melakukan lisensi, dan rencana pengembangannya disertai dengan data dukung sumber daya yang dimilikinya. Selanjutnya Kepala Kepala Badan litbang akan memberikan keputusan menerima atau menolak permohonan lisensi. Apabila permohonan disetujui maka lisensi akan diberikan dalam bentuk lisensi eklusif atau non eklusif.

\section{d. Proses Mediasi}

Calon mitra kerja sama yang terpilih kemudian diundang untuk melakukan mediasi 
perjanjian lisensi, bersama-sama dengan Badan litbang. Dalam mediasi tersebut dibahas mengenai pasal-pasal yang berhubungan dengan:

1) Definisi atau pengertian

2) Maksud dan tujuan

3) Ruang lingkup

4) Jangka Waktu

5) Pemberian Lisensi

6) Hak dan Kewajiban Para Pihak

7) Pemesanan Bahan Baku Produksi

8) Pembayaran Bahan Baku Produksi

9) Pembayaran royalti

10) Pembukuan dan Pelaporan

11) Verifikasi

12) Penyelesain Sengketa

13) Keadaan Force Majure

14) Korespondensi

15) Pemutusan Perjanjian

16) Akibat Pemutusan Perjanjian

17) Lain-lain

18) Perubahan dan,

19) Penutup.

Besar royalti ditetapkan sesuai ketentuan yang berlaku. Para pihak yang terlibat dalam mediasi ini membuat kesepakatan tentang jenis lisensi, apakah lisensi eklusif atau lisensi noneklusif. Perjanjian dilakukan secara eklusif apabila dalam implementasinya memerlukan teknologi tinggi dan akura serta padat modal.

\section{e. Proses Penyusunan Naskah Perjanjian}

Prosedur penyiapan perjanjian kerjasama adalah sebagai berikut:

1) Balai Litbang menyusun draft awal naskah perjanjian

2) Pembahasan internal lingkup Sekertariat Litbang

3) Pembahasan dengan Unit Kerja penemu dan pihak mitra untuk menyusun draft naskah perjanjian berdasarkan kesepakatan para pihak

4) Draft naskah perjanjian hasil kesepakatan para pihak diberikan paraf persetujuan oleh Pimpinan Unit Kerja Pemkrasa kemudian diserahkan kepada Pimpinan Unit Kerja yang menangani aspek Hukum Lingkup Sekertariat litbang untuk diberikan persetujuan dari aspek hukum

5) Pimpinan Badan Litbang menyampaikan draf perjanjian yang telah diparaf sesuai butir 4 kepada Kepala Badan Litbang melalui Sekertaris Badan Litbang untuk dimintakan pesetujuan

6) Apabila naskah perjanjian pada butir 5 disetujui maka dapat dilakukan penandatangan naskah perjanjian, sedangkan apabila tidak disetujui dilakukan pembahasan ulang atau dihentikan pembahasannya sesuai arahan Kepala Badan Litbang. 


\section{f. Proses Penandatangan Perjanjian Lisensi}

Penandatanganan kerjasama lisensi dilakukan oleh penemu teknologi dengan mitra kerjasama lisensi dan disahkan oleh Kepala Badan Litbang. Naskah perjanjian yang telah di tandatangani diberi nomor TU Unit Kerja Penandatanganan dan pihak mitra untuk kemudian disimpan, dan satu salinan disampaikan kepada Biro Hukum dan Informasi Publik melalui Sekertariat Badan Litbang. Setelah perjanjian ditandatangani, maka surat perjanjian tersebut didaftarkan ke instansi yang berwenang (Ditjen HKI) agar mempunyai kekuatan hukum.

\section{g. Proses Verifikasi}

Balai Badan Litbang bersama tim verifikasi dari unit kerja masing-masing instansi melakukan verifikasi secara periodik atas pelaksanaan lisensi sesuai dengan perjanjian. Materi yang diverifikasi meliputi data produksi, promosi distribusi dan penjualan. Berdasarkan hasil verifikasi dapat diketahui apakah perjanjian lisensi telah dilaksanakan sesuai rencana atau belum. Hasil verifikasi tersebut selanjutnya dilaporkan kepada Kepala Badan Litbang melalui forum yang diwakili oleh Kabid Kerjasama dan Pendayagunaan Hasil Penelitian (KSPHP) masing-masing unit kerja setiap instansi. Pembahasan laporan verifikasi mencangkup laporan kinerja masing-masing kerjasama lisensi.
Untuk kerjasama lisensi yang belum berjalan sesuai dengan perjanjian, forum Kabid KSPHP (diharapkan memberikan saran dan rekomendasi pemecahan dan tindak lanjut). Sedangkan untuk perjanjian lisensi yang sudah berjalan baik, akan dilaporkan besaran jumlah royalti yang harus dibayarkan oleh mitra kerjasama lisensi. Kemudian Badan Litbang akan mengirimkan surat tagihan royalti dalam bentuk invoice kepada mitra kerjasama lisensi disertai dengan batas waktu pembayaran royalti berdasarkan tanggal jatuh tempo. Apabila jatuh tempo telah lewat tidak dilakukan pembayaaran maka perusahaan di kenakan denda sebesar 2\% (dua persen) per bulan. Setelah menerima invoice tagihan royalti, maka mitra kerja sama wajib menyetorkan royalti hasil alih teknologi tersebut ke bank.

\section{Kendala komersialisasi pada instansi pemerintah}

Adapun pada pelaksaan alih teknologi melalui kerjasama lisensi masih ditemui beberapa kendala baik teknis, pasar budaya maupun regulasi. Kendala tersebut antara lain:

a. Teknis : kinerja beberapa teknologi yang belum konsisten dan belum siap dikembangkan dalam skala industri. Hal-hal tersebut disebabkan teknologi yang dilisensikan belum siap untuk diproduksi massal, sehingga tiap invensi terlebih dahulu perlu dilakukan penilaian tingkat kesepian teknologinya. 
b. Pasar : terbatasnya pasar pada teknologi tertentu menjadi suatu penghambat dalam pengembangan hasil teknologi yang telah dikembangkan

c. Budaya : masih bertahannya terhadap metode bekerja yang sudah tidak efisien untuk dilakukan untuk era sekarang sehingga membuat terhambatnya upaya menerapkan teknologi dan rendahnya kemampuan sumber daya manusia mitra kerjasama dalam menerima transfer knowledge dari pemilik teknologi

d. Regulasi : pendafataran izin edar bagi hasil invesi, yang terkadang mengalami kesulitan beredar karena perizinan pajak yang cukup memakan waktu.

\section{Analisis penyebab kendala komersialisasi}

Peran lembaga penelitian dan pengembangan (litbang) merupakan salah satu faktor penentu pererkembangan perekonomian di suatu negara. Hasil pemanfaatan ilmu pengetahuan yang diaplikasikan dalam paten dan lisensi menjadi tolak ukur bahwa teknologi yang dihasilkan oleh negara tersebut mutakhir dan bermanfaat dalam pemecahan maslaha di

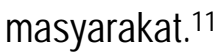

Di indonesia lembaga litbang wajib mengusahakan alih teknologi kekayaan intelektual. Dalam melaksanakan kewajibannya lembaga

\footnotetext{
${ }^{11}$ Seminar Naisonal Technopreneurship dan Alih teknologi 2015.hlm.106
}

litbang wajib membentuk unit kerja yang bertanggung jawab dalam pelaksaan pengelolaan dan alih teknologi kekayaan intelektual serta hasil kegiatan penelitian dan pengembangan di dilingkunya sesuai dengan bunyi Pasal 16 Peraturan Pemerintah Nomor 20 Tahun 2005 tentang Alih Teknologi.

Pada tahap komersialisasi terdapat faktorfaktor yang mempengaruhi suatu invensi bisa masuk didalam kegiatan pasar melalui perjanjian lisensi dengan pihak industrial dan menghasilkan keuntungan. Faktor-faktor yang menjadi kendala suatu invensi berhasil dikomersialkan dibagi menjadi 2 (dua) yaitu Faktor internal dan faktor ekternal.

a. Faktor Internal

Faktor internal merupakan faktor yang berasal dari pemahaman peneliti, intensi hasil peneliti dan kesempatan. Faktor internal terbagi menjadi beberapa, antara lain:

1) Pemahaman peneliti mengenai lisensi yang masih sangat minim

Pemahaman peneliti mengenai lisensi masih sangat minim, dimana pada dasarnya output kinerja peneliti bukan didasarkan oleh lisensi yang dihasilkan. Inventor menganggap bahwa lisensi merupakan hasil sampingan dari pemanfaatan hasil penelitian. Lebih dari $50 \%$ inventor cenderung melakukan kerja sama tidak melalui lisensi, melainkan dengan kotrak lain. Dengan demikian proses komersialisasi dari hasil pernelitian tidak 
beorientasi pada paten. Adanya kerjasama penelitian pada umumnya merupakan kerja sama yang berorientasi pada kebutuhan dari suatu instansi atau industri dimana pihak luar terlebih dahulu mengajukan usulan kerjasama.

2) Hasil penelitian tidak marketable

Pada umumnya hasil penelitian yang dihasilkan oleh lembaga litbang bersifat penelitian dasar. Sebagian besar penelitian bukan berdasarkan data analisa pasar atau masih belum bersifat marketable. Selain itu penelitian yang dihasilkan oleh inventor tekadang belum bisa diterima (acceptable) baik oleh industri maupun suplier dikarenakan sifat penelitian bukan sebuah produk jadi melainkan masih prototype yang masih pada tahap trial and error sehingga produk yang dihasilkan masih belum bisa diaplikasikan. Sehingga diperlukannya investasi lebih dari luar dalam penyempurnaan hasil penelitian.

3) Kalah bersaing dengan pihak industri

Untuk beberapa ruang lingkup, pihak industri masih lebih unggul dalam pengembangan berbasis aplikasi perangkat elektronik, otomotif, dsb. Hasil penelitian yang telah di lisensi cenderung pada produk paten yang bersifat kimian dan elektronika, dimana produk yang dihasilkan berupa kosmetik, pupuk, obat dll yang sudah teruji.Selain itu teknologi yang dihasilkan terkadang teknologi yang sudah tidak mengikuti kebutuhan masa kini atau ketinggalan jama dengan teknologi dari negara lain.

\section{b. Faktor Ekternal}

Dalam proses lisensi faktor ekternal memiliki peran yang sangat penting dimana faktor eksternal menjalankan peran sebagai penghubung inventor dan industri. Faktor internal tebagi menjadi beberapa, antara lain:

1) Biaya dan Operasional

Dibutuhkannya sebuah badan yang mengelola secara mandiri proses komersialisasi yang disebut dengan Technology Tranfer Office (TTO) seperti yang dilaksanakan pada negara Amerika, Uni Eropa, dan Jepang. Adanya TTO dapat memberikan pengaruh positif kepada inventor, dimana biaya dan operasional dari kegiatan komersialisasi sepenuhnya ditanggung oleh TTO. Selain itu proses pendampingan terhadap komersialisasi dan alih teknologi lebih disukai oleh inventor sehingga akan lebih mudah. Selama ini invensi menilai sulit menemukan secara mandiri industri yang ingin bekerja sama ataupun indeks kepuasan mayarakat yang akan menjadi wadah tranfer teknologi. Paten yang dihasilkan oleh litbang kemudian dicari potensi pasar dan skema proyeksi bisnisnya. Potensi TTO juga menjadi sumber arus kas dari investasi lisensi paten, dimana pencatatan dilakukan secara berkala hingga jangka waktu tertentu. Selain itu dapat menjadi sumber pengembangan dari potensi 
paten yang sudah ada, dimana pada masa paten yang sudah mencapai masa public domain dapat di upgrade dengan hasil pengembangan penilitian yang lebih baik.

2) Publikasi (kerjasama)

Dimana informasi invensi hanya didapatkan oleh kalang minoritas atau tertentu. Dalam hal ini penekanan terhadap branding dianggap penting sehingga setiap lapisan masyarakat dapat mengetahui tentang hasil penelitian sehingga akan memudahkan industri dalam proses komersialisasi. Hal ini dapat diantisipasi dengan perlunya penyelenggaraan secara berkala kegiatan pameran, temu bisnis maupun workshop baik di internal maupun kerja sama dengan pihak lain.

Dari pemaparan faktor diatas maka suatu usaha peningkatan komesialisasi harus melihat dari faktor internal (individu) dan aspek ekternal (instansi). Dimana aspek internal dipengaruhi oleh pemahaman penelitian tentang lisensi, intesitas penelitian yang bersifat maketable dan applicable. Disisi lain, aspek ekternal meliputi adanya suatu Technology Tranfer Office (TTO) dimana TTO berfungsi dalam pebiayaan, operasional dan publikasi sebagai media penghubung hasil penelitian dengan indutri.

Dalam peningkatan lisensi paten perlu adanya pendampingan dan pencarian dan pengembangan stakeholder, dalam rangka memperluas sarana publikasi hasil pemanfaatan hasil-hasil paten yang sedang atau telah diberikan paten, aktif dalam penyelenggaraan kegiatan pemeran temu bisnis, workshop.

\section{PENUTUP}

\section{Simpulan}

a. Dalam proses komersialisasi suatu invensi Badan Penelitian dan Pengembangan setiap instansi menempuh beberapa mekanisme antara lain : a. Mendaftarkan Inovasi tersebut kepada Ditjen HKI, agar inovasi tersebut mendapatkan perlindungan; b. Melakukan promosi terhadap hasil inovasi yang telah mendapatkan perlindungan $\mathrm{HKl}$; $\mathrm{c}$. Menyeleksi Calon Mitra yang mengajukan permohonan lisensi terhadap inovasi tersebut;d. Melakukan mediasi tentang perjanjian lisensi; e. Menyusun naskah perjanjian lisensi;f. Mengawal perjanjian lisensi tersebut hingga di tanda tangani masing-masing pihak; g. Melakukan verifikasi terhadap inovasi yang dilisensikan;h. Menerima hasil royalti.; i. Setelah diterbitkannya Keputusan Menteri Keuangan Nomor 72/PMK.02/2015, Badan Penelitian dan Pengembangan memberikan imbalan kepada Inventor yang inovasinya berhasil komersial

b. Pada prakteknya, setiap instansi menemuii berbagai kendala antara lain :

a. Teknis : kinerja beberapa teknologi yang belum konsisten dan belum siap dikembangkan dalam skala industri. Hal- 
hal tersebut disebabkan teknologi yang dilisensikan belum siap untuk diproduksi massal, sehingga tiap invensi terlebih dahulu perlu dilakukan penilaian tingkat kesepian teknologinya.

b. Pasar : terbatasnya pasar pada teknologi tertentu menjadi suatu penghambat dalam pengembangan hasil teknologi yang telah dikembangkan

c. Budaya : masih bertahannya terhadap metode bekerja yang sudah tidak efisien untuk dilakukan untuk era sekarang sehingga membuat terhambatnya upaya menerapkan teknologi dan rendahnya kemampuan SDM mitra kerjasama dalam menerima transfer knowledge dari pemilik teknologi

d. Regulasi : pendafataran izin edar bagi hasil invesi, yang terkadang mengalami kesulitan beredar karena perizinan pajak yang cukup memakan waktu.

c. Ada berapa faktor yang mempengaruhi terjadinya kendala pada sektor pasar antara lain adalah:

a. Faktor internal

Faktor Internal terbagi menjadi beberapa faktor antara lain:

1) Pemahaman peneliti mengenai lisensi yang masih sangat minim

2) Hasil peneliti yang tidak sesuai dengan kebutuhan pasar

3) Kalah bersaing denga pihak industri b. Faktor ekternal

1) Biaya dan operasional

2) Kerjasama dengan pihak industri yang masih kurang

\section{Saran}

Adanya peran Balitbang dalam memberi pemahaman terhadap inventor bahwa penemuan inventor haruslah sesuatu teknologi yang dibuthkan masyarakat saat ini dan dibutuhkan pasar, diharapkan dari situ inventor dapat lebih menciptakan teknologi yang tepat guna, sehingga dalam proses komersialisasi. Selain ini diharapkan bagi Balitbang untuk meningkatakan pola kemitran dengan Industri untuk memperluas jaringan dalam proses komersialisasi.

\section{DAFTAR PUSTAKA}

\section{Buku}

Sunggono, Bambang, 2006, Metode Penelitian Hukum, Jakarta: PT RajaGrafindo Persada.

Hadari Nawawi \& Mimi Martini, 1994, Penelitian Terapan, Yogyakarta: Gajahmada University.

Muhammad Djumhana dan R. Djubaedillah, 2014, Hak Milik Intelektual Sejarah, Teori dan Praktiknya di Indonesia, Bandung: Citra Aditya Bakti.

Roisah, Kholis, 2013, Dinamika Perlindungan HKI Indonesia Dalam Tatanan Global, Semarang: Pustaka Magister. 
Soekanto, Soerjono, 1984, Pengantar Penelitian Hukum, Jakarta: UI Press.

Soerjono Soekanto dan Sri Mamuji, 2011, Penelitian Hukum Normatif, suatu Tinjauan Singkat, Jakarta: PT Raja Grafindo Persada.

\section{Peraturan Daerah}

Peraturan Daerah Kota Bukit Tinggi Nomo 2 Tahun

2016 tentang Retribusi Tempat Rekreasi

dan Olahraga

\section{Seminar}

Seminar Nasional Technopreneurship dan Alih

teknologi 2015

\section{Internet}

http://www.chinadaily.com.cn/beijing/2015-

08/19/content_21645081.htm;diakses

tanggal 28 Februari 2017; pukul 14.09 wib 